\title{
DYNAMICS OF BORDER VEGETATION AND EDAPHIC- CLIMATOLOGY OF CLEARINGS IN AN AREA OF CAATINGA IN THE SEMI-ARID REGION OF BRAZIL.
}

\author{
Azenate Campos Gomes ${ }^{1}$, Jacob Silva Souto ${ }^{2}$, Alecksandra Vieira de Lacerda ${ }^{3}$ \\ 1 *Federal University of Paraíba, Health Sciences Center, Department of Pharmaceutical Sciences, João Pessoa, Paraíba, Brazil - \\ azenatecampos@gmail.com (*AUTHOR FOR CORRESPONDENCE). \\ ${ }^{2}$ Federal University of Paraíba, Department of Phytotechnology and Environmental Sciences, Center of Agrarian Sciences, Areia, Paraíba, \\ Brazil - jacob_souto@yahoo.com. \\ ${ }^{3}$ Federal University of Campina Grande, Center for the Sustainable Development of the Semi-Arid, Academic Unit of Development \\ Technology, Sumé, Paraíba, Brazil - alecvieira@yahoo.com.br.
}

Received for publication: 31/05/2018 - Accepted for publication: 18/10/2018

\begin{abstract}
Resumo
Dinâmica da vegetação de borda e edafoclimatologia de clareiras em uma área de Caatinga no Semiárido brasileiro. O uso e ocupação insustentável das áreas Semiáridas têm resultado, ao longo do seu processo histórico, em fortes impactos negativos devido a abertura de clareiras nas áreas de Caatinga, as quais necessitam ser identificadas e estudadas para reversão desse quadro. Objetivou-se com este trabalho analisar a dinâmica da vegetação de borda e edafoclimatologia de clareiras em uma área de Caatinga no Município de Sumé-PB. O trabalho foi desenvolvido na Área Experimental Reservada para Estudos de Ecologia e Dinâmica da Caatinga do LAEB/CDSA/UFCG (7³9'38.8' S e 36 53'42.4' ' W, com $538 \mathrm{~m}$ de altitude). As clareiras foram isoladas, e monitoradas entre 2013 e 2015 , sendo realizadas coletas de solo e dos dados agrometeorológicos. Considerouse como indivíduos de borda os arbustos e árvores vivos com diâmetro ao nível do solo e altura $\geq 0,03 \mathrm{~m}$ e $\geq 1,0$ $\mathrm{m}$ respectivamente. Os maiores valores de densidade do solo foram observados para as clareiras que apresentaram os menores índices de matéria orgânica. $62 \%$ das clareiras tiveram um aumento na sua área em função da alta mortalidade de Croton blanchetianus Baill. e 38\% tiveram sua área reduzida devido a colonização de jovens ingressantes, principalmente de Jatropha mollissima (Pohl) Baill. A composição florística de borda compreendeu seis espécies distribuídas em seis gêneros e quatro famílias, sendo Fabaceae e Euphorbiaceae as mais representativas. O número de indivíduos de borda e a mortalidade registrada se mostraram totalmente correlacionadas com os parâmetros climáticos. Portanto, apesar das clareiras estar em processo de regeneração natural os fatores climáticos têm influenciado fortemente no retardamento desse processo.
\end{abstract}

Palavras-Chave: Clareiras antrópicas, regeneração natural, parâmetros edafoclimatológicos, floresta tropical seca.

\begin{abstract}
The use and unsustainable occupation in the semi-arid areas have resulted throughout its historical process in strong negative impacts by opening clearings in the areas of Caatinga, which need to be identified and studied to reverse this situation. The objective of this work was to analyze the dynamics of border of vegetation and edaphic-climatological clearings in a Caatinga area in the municipality of Sumé, state of Paraíba, Brazil. The study was conducted in the Experimental Area Reserved for Ecology and Dynamic Studies of the Caatinga of LAEB/CDSA/UFCG (7'39'38.8" S and 36 $53^{\prime} 42.4^{\prime \prime} \mathrm{W}$, with $538 \mathrm{~m}$ of altitude). The clearings were isolated, and monitored between 2013 and 2015, soil and agrometeorological data were collected. Shrubs and live trees with diameter at ground level and height $\geq 0.03$ and $\geq 1.0 \mathrm{~m}$ respectively were considered as border individuals. The highest values of soil density were observed for the clearings that presented the lowest levels of organic matter. $62 \%$ of the clearings had an increase in their area due to the high mortality of Croton blanchetianus Baill. and 38\% had their area reduced due to the colonization of young, mainly Jatropha mollissima (Pohl) Baill. The floristic composition of the border comprised six species distributed in six genera and four families, being Fabaceae and Euphorbiaceae the most representative. The number of border individuals and recorded mortality were fully correlated with climatic parameters. Therefore, although the clearings are in the process of natural regeneration, climatic factors have strongly influenced the delay of this process.

Keywords: Anthropic clearings, natural regeneration, climatological edaphic parameters, dry tropical forest.
\end{abstract}

\section{INTRODUCTION}

The definition of clearings has been widely discussed in the literature, in which several concepts have been pointed out. One of the most adopted is that of Martins et al. (2008) that define them as spaces in the forest canopy whose environmental conditions differ from those of the closed canopy where resources such as light are

FLORESTA, Curitiba, PR, v. 49, n. 3, p. 523 - 532, jul/set 2019.

Gomes, A. C. et.al.

ISSN eletrônico 1982-4688

DOI: $10.5380 /$ rf.v49 i3.59715 
no longer controlled by shading.

The clearings are formed by a rupture in the structure of the forest canopy, which can be caused by natural or anthropic factors and its intensity will determine its size that together with climatic factors and soil uses establish the sequencing of colonizing species.

Structural features of clearings, such as their size, type of disturbance and geometry, may vary from one clearing to another (BROWN, 1993), and function as additional factors in the construction of differentiated habitats for colonization by plant species. Therefore, the structural characteristics influence the composition and the spatial arrangement of the species in clearings, being the spaces generated a functional character in the process of ecological succession of these environments.

Despite the importance of knowledge of the operation and dynamics of clearings, there are few studies that address this issue in detail, especially when referring to the surroundings and edge for later understanding of the fillers.

Methodological tests for area calculations and monitoring of evaluations of the regenerating stratum in tropical forests are the most common (BROKAW, 1982). In Brazil, most of the work is centered on tropical rainforests (FERREIRA et al., 2010) and semi-deciduous forest (RIBEIRO et al., 2011).

Considering the Caatinga Biome and the occurrence of a significant number of clearings, mainly of anthropic origin, there are no studies that address the dynamics of these environments. Only some authors describe in the methodologies of their work some areas with presence of clearings, but without any definition of their meaning or detailed characterization.

Andrade et al. (2015) describe an environment in São João do Cariri, characterized by caatinga with rickety and sparse vegetation with large clearings and presence of rock outcrops, where the soil remains uncovered during practically all the year. In the Backwood of Paraíba, Anselmo et al. (2014), when studying the area of arboreal caatinga (Amburana cearensis (Allemão) A.C.Sm., Anadenanthera colubrina (Vell.) Brenan, Commiphora leptophloeos (Mart.) JBGillett, Cnidoscolus quercifolius Pohl e Poincianella pyramidalis (Tul.) LPQueiroz), noticed the presence of clearings where the herbaceous stratum is dominated by Mesosphaerum suaveolens (L.) Kuntze. Guedes et al. (2012) add that in this same area besides the dominance of M. suaveolens there is also the panasco grass (Aristida sp.)

Taking into account the lack of detailed studies on clearings and the urgent need of its understanding to support the ecological processes of vegetation, this study aimed to analyze the dynamics of border vegetation and edaphoclimatology of clearings in an area of Caatinga in the Municipality of Sumé, Semi-arid of Paraíba, Brazil.

\section{MATERIAL AND METHODS}

\section{Area of study}

The research was carried out in the municipality of Sumé, located in the Western Cariri micro region, specifically in the Reserved Experimental Area for Studies on Ecology and Dynamics of the Caatinga Laboratory of Ecology and Botany ( $07^{\circ} 39^{\prime} 38.8^{\prime \prime} \mathrm{S}$ and $36^{\circ} 53^{\prime} 42.4^{\prime \prime} \mathrm{W}$, with $538 \mathrm{~m}$ of altitude), belonging to the Center for the Sustainable Development of the Semi-Arid of the Federal University of Campina Grande.

According to the classification of Köppen, the climate of the region is of the type BSh, that is, dry (semiarid) climate. The rainy season is concentrated in three months of the year with annual average precipitation of $590 \mathrm{~mm}$. The annual average temperature is $24^{\circ} \mathrm{C}$, the average annual sunshine is 2800 hours and the average annual evaporation in the class A tank is $2900 \mathrm{~mm}$. The predominant soil is the Luvissolo, representative of the Semi-arid zone, with slow permeability, with depth around $0.5 \mathrm{~m}$ to $1.0 \mathrm{~m}$, and in many places rock outcrop occurs. The relief is slightly undulating to corrugated (SRINIVASAN et al., 2003).

The adult vegetation of the studied area is characterized mainly by species of Euphorbiaceae, Fabaceae and Cactaceae (LACERDA et al., 2018). Related to ecological succession, J. mollissima and C. blanchetianus stood out in the young species bank of the shrub strata in the year of 2013 and P. pyramidalis in the arboreal stratum in 2014 (FRAGOSO et al., 2015).

Cariri of Paraíba is a "rural territory", which is evidenced by the economic profile of the region. Not unlike, the study area is also the result of economic exploitation, which is characterized by the presence of anthropic clearings.

The clearings present in the study area were fruits of logging by cutting wood to supply firewood to local bakeries and for the production of charcoal for non-commercial use. For 26 years, the supply of firewood for bakeries has ceased and extensive goat farms have been started until 2009, when this area became part of the Center for Sustainable Development of the Semi-Arid Region. In 2011 this site was surrounded, thus becoming the Reserved Experimental Area for Ecology and Dynamic Studies of the Caatinga of the Laboratory of Ecology and Botany. This site has 1.02 ha and 96 contiguous plots of $10 \times 10 \mathrm{~m}$ were arranged in it (Figure 1). 

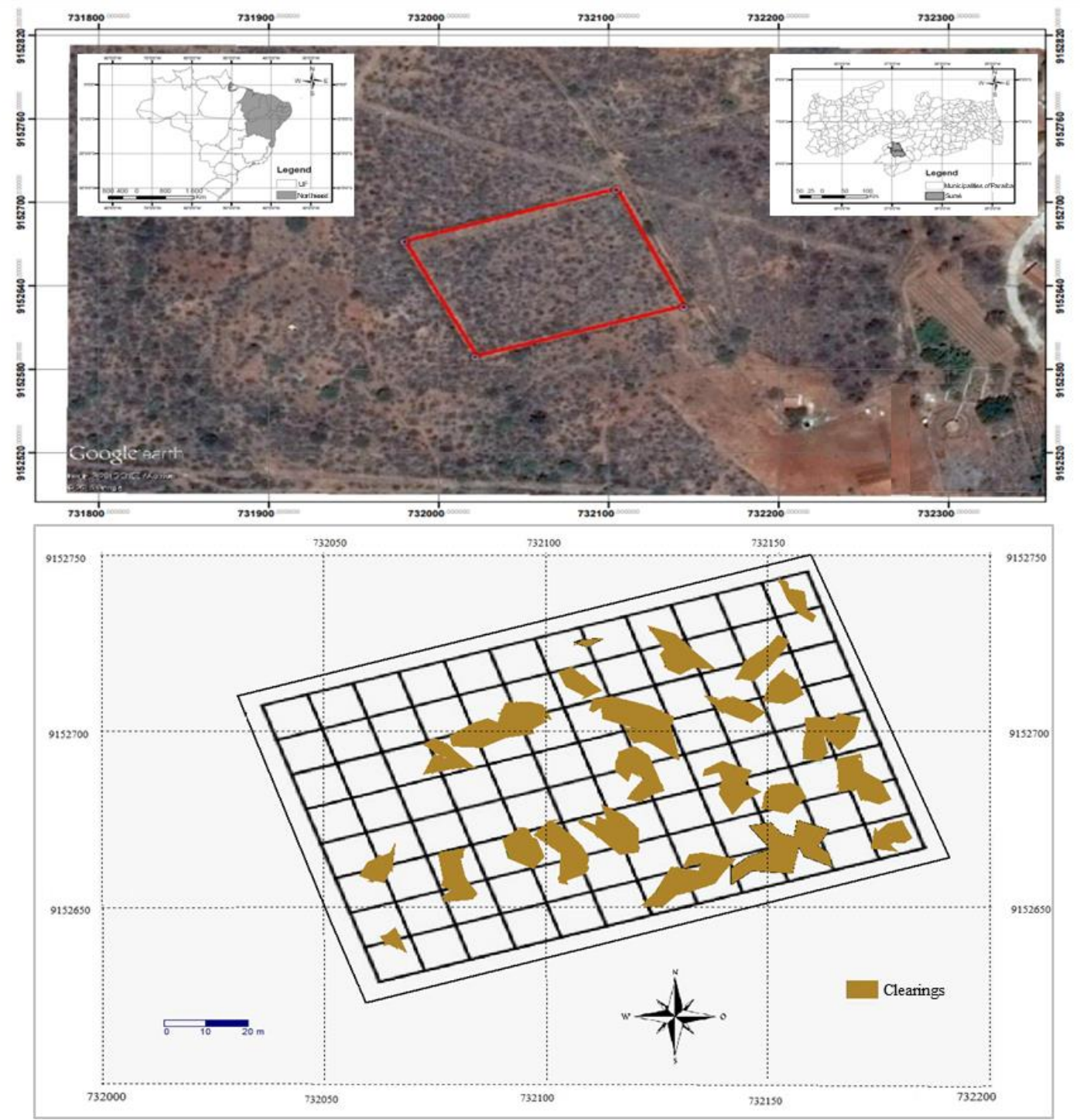

Figure 1. Localization of the study area with the presence of clearings in the Caatinga area in the city of Sumé, Paraíba, Brazil.

Figura 1. Localização da área de estudo com a presença de clareiras em área de Caatinga no Município de Sumé, Paraíba, Brasil.

\section{Data Collection and Analysis}

For the identification of clearings, the distance between the stems of trees and shrubs with soil diameter at ground level (DNS) $\geq 0,03 \mathrm{~m}$ and height $\geq 1,0 \mathrm{~m}$ was measured, which served as the limit for the calculation of the area in $\mathrm{m}^{2}$. Areas with openings from $5.0 \mathrm{~m}^{2}$ were considered as a clearing. Thus, it were selected 24 clearings distributed in an area of 0.96 ha, which were isolated by waxed line, to avoid the entry of people in the area and, consequently, changes in their evolutionary framework.

The clearing area was obtained by creating polygons in GPS TrackMaker PRO. In the field, the trees and shrubs that demarcated the limits of the clearings were georeferenced, so that with each significant change of direction, a vertex was marked with the aid of GPS, followed by a line of the shrubs and trees that appeared as vertex of a polygon.

For the classification of clearings in natural and/or anthropic, observations were made in the field, such as the presence and quantitative of burnt traces, wood cuttings, falling of individuals or twigs (BROKAW, 1982), exposed soil with rock formation and soil removal for buildings, uprooting and quantitative shrubs and dead trees. The analysis of clearings between the years of 2013 and 2015 occurred through the reduction or increase of the area by the mortality and/or entrance of the arboreal-shrub individuals of the environment.

FLORESTA, Curitiba, PR, v. 49, n. 3, p. 523 - 532, jul/set 2019.

Gomes, A. C. et.al.

ISSN eletrônico 1982-4688 
In order to collect data over the edaphic conditions, two simple samples were collected with a $20 \mathrm{~cm}$ depth in each clearing that. After being mixed, composed a composte sample by clearing for physical and chemical analysis. The material was taken to the Laboratory of Soil Chemistry and Fertility of the DSER/CCA/UFPB, for determinations of chemical and physical attributes (EMBRAPA, 2013).

For the analysis of the climatic variables, it was considered monthly historical data of precipitation of a historical series of 30 years and data of air temperature, and of the soil at $10 \mathrm{~cm}$ depth, relative humidity of the air and humidity of the ground to $10 \mathrm{~cm}$ depth in the period from January 2013 to December 2015, based on data from the AESA Post in Sumé (Latitude (Grades) -7.6736; Longitude (Grades) -36.8964).

\section{RESULTS}

24 clearings of anthropic origin, which are in the process of regeneration, were totalized, being possible, still, the observation of the remains of the tree trunks and cutand burned bushes, distributed in $96 \%$ of the total of the clearing studied. Only 4\% did not have these characteristics; however, the individuals of its edges had presented some shafts, signaling anthropic actions that occurred in the past.

It is worth noting that even after the cessation of cutting and partial burning of the wood, although subject to goat grazing, together with four years of total isolation, it was not possible to recolonize the open areas, becoming evident that ecological processes for recolonization of clearings occur slowly.

In relation to the chemical attributes of the soils of the clearings (Table 1), all had a high base saturation (v\%), which varied from $85.56 \%$ to $93.11 \%$ and did not have the presence of exchangeable Aluminum.

Table 1. Chemical attributes of the soil of anthropic clearings in Caatinga area in the Paraíba Semi-arid region, Brazil. Tabela 1. Atributos químicos do solo de clareiras antrópicas em área de Caatinga no Semiárido da Paraíba, Brasil.

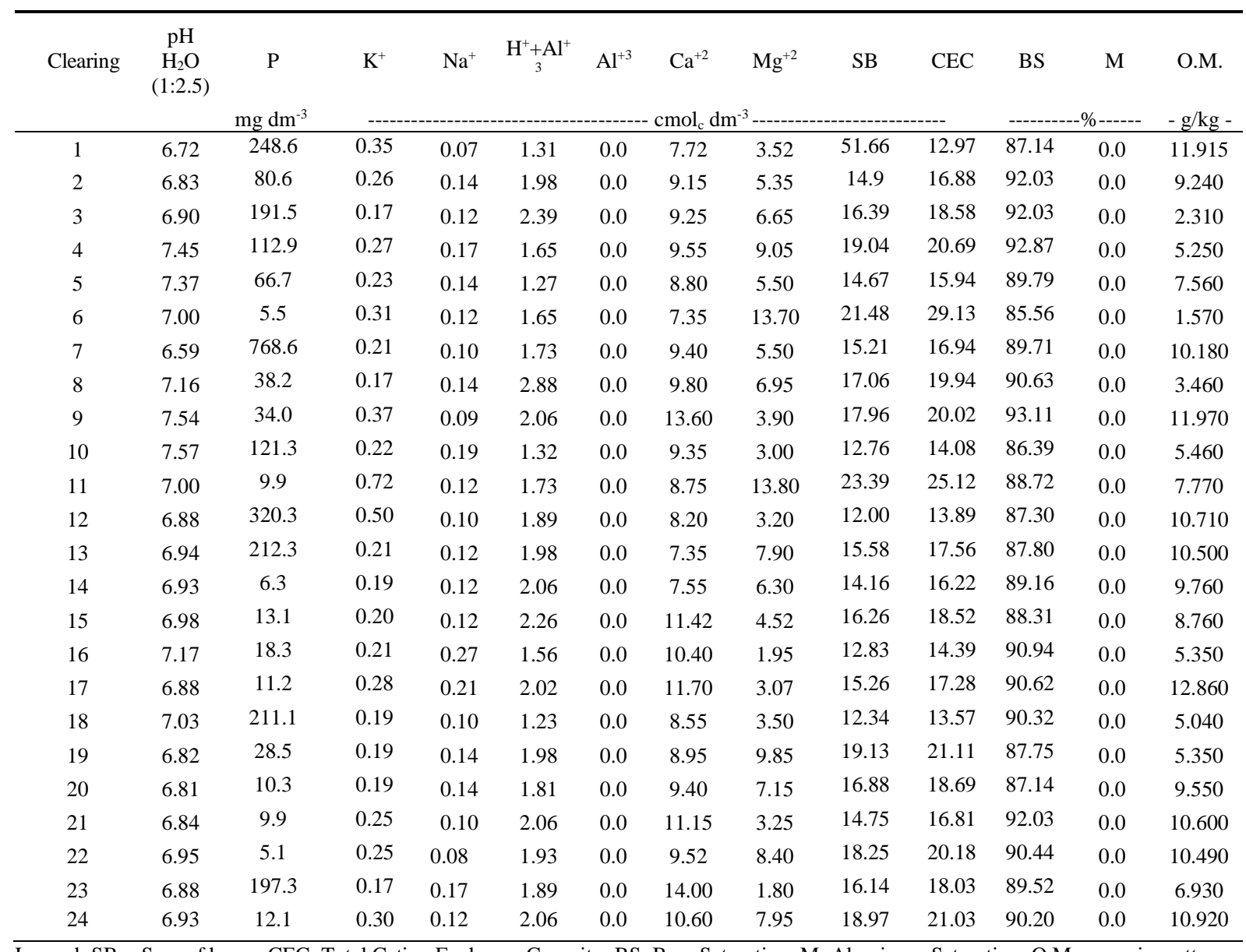

Legend: SB = Sum of bases; CEC: Total Cation Exchange Capacity; BS: Base Saturation; M: Aluminum Saturation; O.M.: organic matter 
Regarding organic matter, all the clearings presented very low values, with variation from 1.57 to 12.86 $\mathrm{g} \mathrm{kg}^{-1}$. The lowest values occurred in the clearings 6, 3,8 and 18, which were characterized by low stands and very stony points.

The predominant textural class was the sandy loam which represented $83 \%$ of the clearings, followed by free sand with $13 \%$ and sandy loam with $4 \%$. In relation to soil density, the highest values were present in the clearings $10,4,12,8,18,5,3$, respectively (Table 2), which were also among those with the lowest organic matter content.

Table 2 - Physical soil attributes in anthropic clearings in Caatinga area in the Paraíba Semi-arid region, Brazil. Tabela 2 - Atributos físicos do solo em clareiras antrópicas em área de Caatinga no Semiárido da Paraíba, Brasil.

\begin{tabular}{|c|c|c|c|c|c|c|c|c|c|c|}
\hline \multirow[t]{2}{*}{ Clearing } & \multicolumn{2}{|c|}{$\begin{array}{c}\text { Sand } \\
\text { Fine coarse } \\
2-0.20 .2-0.05 \\
--- \text { mm - - }\end{array}$} & $\begin{array}{c}\text { Silt } \\
0.05- \\
0.002 \\
--\mathrm{mm}--\end{array}$ & $\begin{array}{c}\text { Clay } \\
<0,002 \\
-\mathrm{mm}-\end{array}$ & $\begin{array}{l}\text { Dispersed } \\
\text { Clay }\end{array}$ & $\begin{array}{l}\text { Degree of } \\
\text { flocculation }\end{array}$ & $\begin{array}{c}\text { Soil } \\
\text { density }\end{array}$ & $\begin{array}{c}\text { Density of } \\
\text { particle }\end{array}$ & $\begin{array}{c}\text { Total } \\
\text { porosity }\end{array}$ & \multirow[t]{2}{*}{ Textural class } \\
\hline & ---- & ------- & $\mathrm{kg}$ & ------ & $-\mathrm{g} / \mathrm{kg}-$ & $-\mathrm{g} / \mathrm{kg}-$ & $-\mathrm{g} / \mathrm{cm}^{3}-$ & $-\mathrm{g} / \mathrm{cm}^{3}-$ & $-\mathrm{m}^{3} / \mathrm{m}^{3}-$ & \\
\hline 1 & 322 & 283 & 272 & 123 & 51 & 576 & 1.38 & 2.65 & 0.48 & Sandy Loam \\
\hline 2 & 384 & 242 & 297 & 77 & 52 & 325 & 1.36 & 2.70 & 0.50 & Sandy Loam \\
\hline 3 & 429 & 261 & 273 & 37 & 76 & 297 & 1.42 & 2.68 & 0.47 & Sandy Loam \\
\hline 4 & 373 & 314 & 278 & 35 & 13 & 629 & 1.51 & 2.89 & 0.48 & Sandy Loam \\
\hline 5 & 391 & 311 & 241 & 57 & 26 & 522 & 1.43 & 2.80 & 0.49 & Free Sand \\
\hline 6 & 323 & 308 & 216 & 153 & 52 & 660 & 1.37 & 2.64 & 0.48 & Sandy Loam \\
\hline 7 & 317 & 316 & 310 & 57 & 26 & 544 & 1.35 & 2.67 & 0.49 & Sandy Loam \\
\hline 8 & 470 & 288 & 219 & 23 & 0 & 1000 & 1.47 & 2.76 & 0.47 & Free Sand \\
\hline 9 & 306 & 322 & 310 & 62 & 26 & 581 & 1.37 & 2.82 & 0.51 & Sandy Loam \\
\hline 10 & 418 & 323 & 214 & 45 & 26 & 422 & 1.52 & 2.85 & 0.47 & Sandy Loam \\
\hline 11 & 307 & 309 & 305 & 79 & 52 & 342 & 1.33 & 2.76 & 0.52 & Sandy Loam \\
\hline 12 & 303 & 315 & 226 & 156 & 51 & 673 & 1.51 & 2.69 & 0.44 & Sandy Loam \\
\hline 13 & 270 & 305 & 350 & 75 & 26 & 653 & 1.34 & 2.78 & 0.52 & Sandy Loam \\
\hline 14 & 339 & 267 & 267 & 127 & 39 & 693 & 1.38 & 2.66 & 0.48 & Sandy Loam \\
\hline 15 & 297 & 309 & 294 & 100 & 59 & 402 & 1.32 & 2.78 & 0.52 & Sandy Loam \\
\hline 16 & 403 & 270 & 282 & 45 & 26 & 422 & 1.31 & 2.72 & 0.52 & Sandy Loam \\
\hline 17 & 285 & 237 & 268 & 210 & 39 & 799 & 1.21 & 2.65 & 0.54 & Sandy Clay Loam \\
\hline 18 & 405 & 332 & 241 & 22 & 13 & 409 & 1.46 & 2.76 & 0.47 & Loam Sand \\
\hline 19 & 373 & 292 & 309 & 26 & 13 & 500 & 1.34 & 2.75 & 0.51 & Sandy Loam \\
\hline 20 & 318 & 267 & 273 & 142 & 52 & 634 & 1.29 & 2.78 & 0.54 & Sandy Loam \\
\hline 21 & 288 & 271 & 298 & 143 & 26 & 818 & 1.29 & 2.70 & 0.52 & Sandy Loam \\
\hline 22 & 277 & 278 & 309 & 136 & 52 & 614 & 1.22 & 2.73 & 0.54 & Sandy Loam \\
\hline 23 & 264 & 296 & 324 & 116 & 53 & 543 & 1.27 & 2.77 & 0.54 & Sandy Loam \\
\hline 24 & 218 & 344 & 287 & 151 & 26 & 828 & 1.25 & 2.79 & 0.55 & Sandy Loam \\
\hline
\end{tabular}

Besides the physical-chemical quality of the soils, the climatic parameters are fundamental in the emergence and reestablishment of natural and anthropic clearings. The average rainfall between the years 1986 and 2015 was of $539.9 \mathrm{~mm}$. However, as a characteristic of the semi-arid region of Brazil, there was a great variability in the annual distribution during this period, in which 2012 was the driest year with only $21 \mathrm{~mm}$ and 1986, 1989 and 2009 were the rainiest with $965.0,917.0$ and $890.2 \mathrm{~mm}$ respectively. In general, it was observed that during this 30 -year period, $50 \%$ of the analyzed years rained below the historical average of $539.9 \mathrm{~mm}$ (AESA, 2015).

Soil temperature and humidity at $10 \mathrm{~cm}$ depth, air temperature and humidity accompanied the variations in precipitation in the years of 2013 and 2015. However, in 2014, the year considered to be more rainy with $658.2 \mathrm{~mm}$, there was no relation of precipitation with the other parameters (Figure 2).

FLORESTA, Curitiba, PR, v. 49, n. 3, p. 523 - 532, jul/set 2019

Gomes, A. C. et.al.

ISSN eletrônico 1982-4688

DOI: $10.5380 /$ rf.v49 i3.59715 


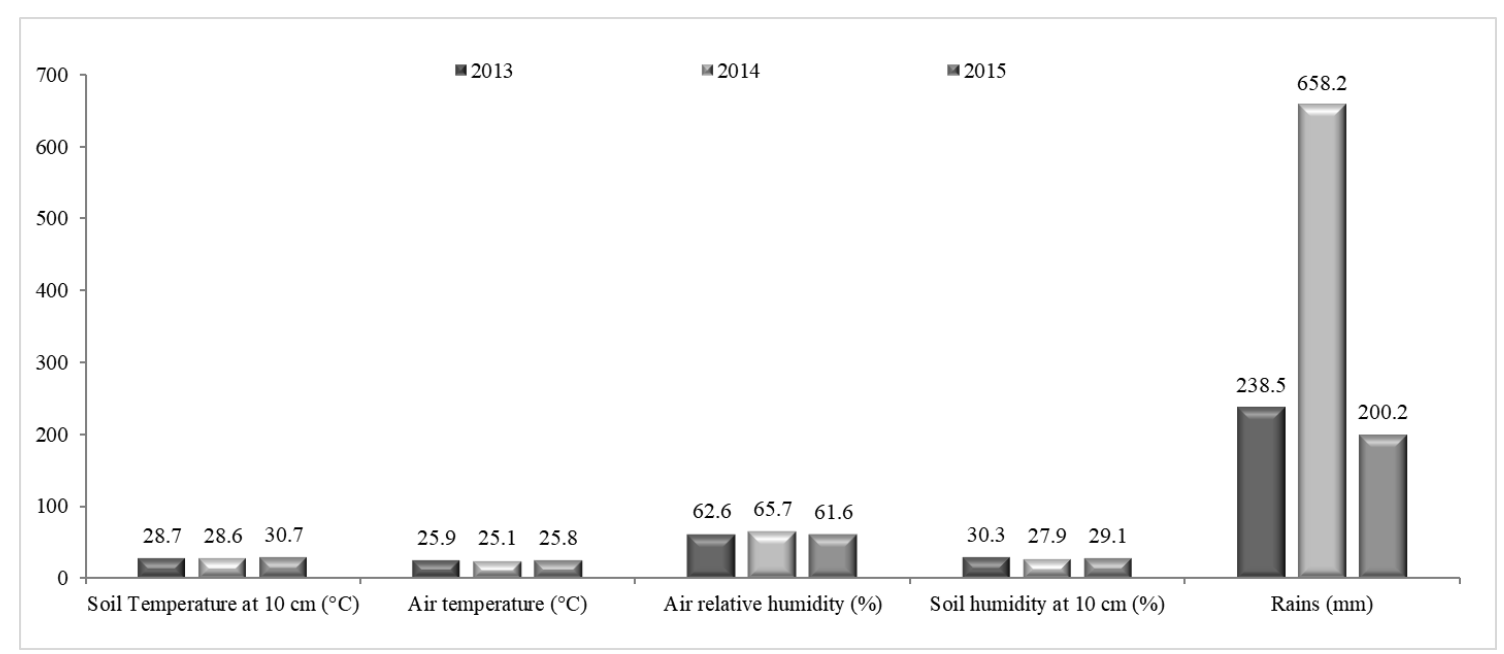

Figure 2. Yearly climatic parameters for the period from January 2013 to December 2015 obtained from the total station of the CDSA / UFCG, Sumé Municipality, Paraíba, Brazil. Source: Aesa (2015).

Figura 2. Parâmetros climáticos anuais para o período de Janeiro de 2013 a Dezembro de 2015 obtidos da estação total do CDSA/UFCG, Município de Sumé, Paraíba, Brasil. Fonte: Aesa (2015).

Considering the 0.96 ha where the contiguious plots of $10 \times 10$ were demarcated, $19 \%$ is occupied by clearings. Between 2013 and 2015, 62\% of the clearings had an average increase of $1.79 \mathrm{~m}^{2}$, with variations of 0.01 to $4.65 \mathrm{~m}^{2}$, according to the mortality of individuals. $38 \%$ of the clearings had their area reduced due to the colonization of young entrants. This reduction occurred on an average of $0.7 \mathrm{~m}^{2}$ per clearing. It was also observed that $66.66 \%$ of the clearings tend to have a spatial grouping, since the separation of the vegetation occurs through a small corridor of trees and shrubs (Figure 3).

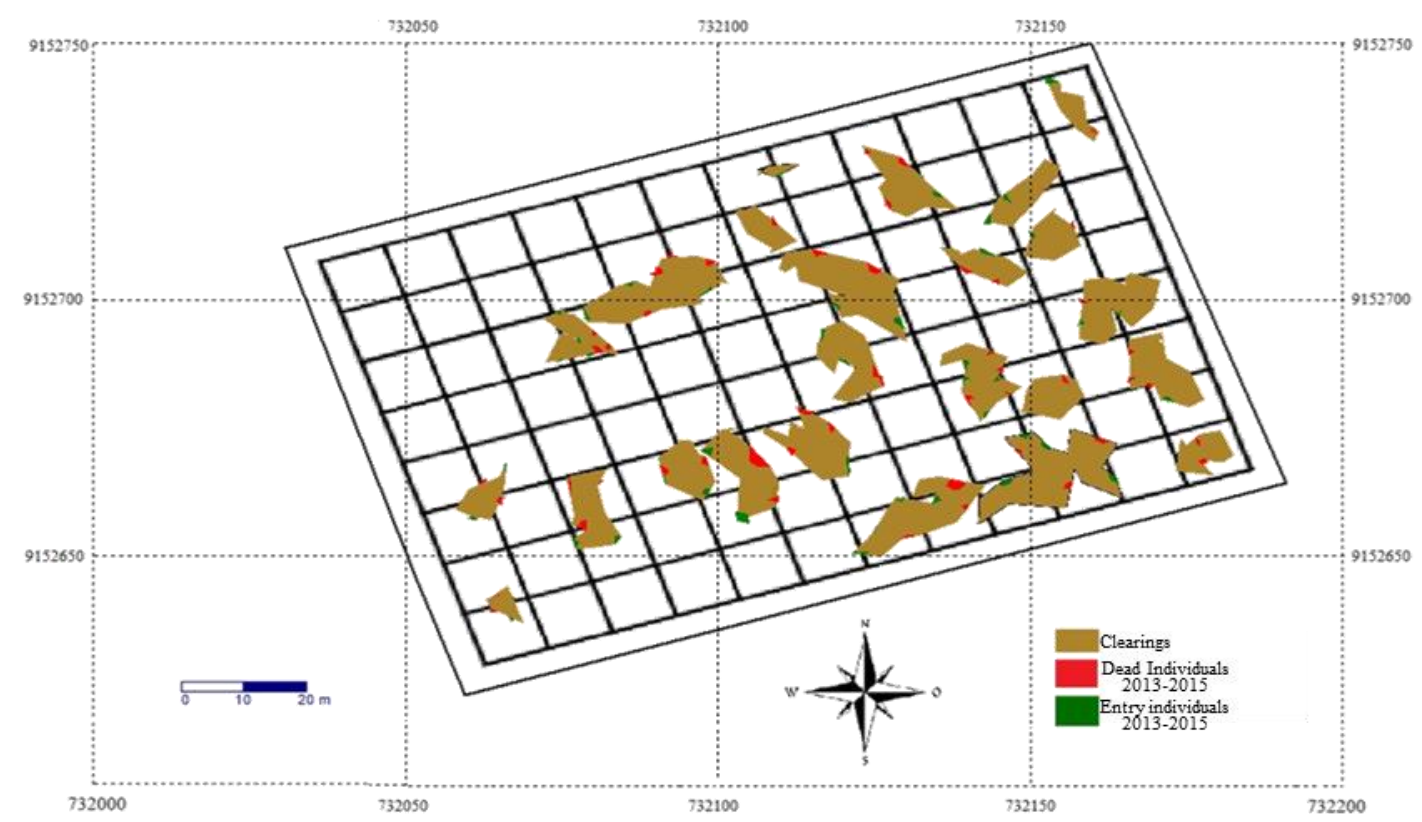

Figure 3. Map of distribution of the entrance of ingressing and mortality rate in the period from 2013 to 2015 in clearings in the Municipality of Sumé-Semi-arid da Paraíba, Brazil.

Figura 3. Mapa de distribuição da entrada de ingressante e taxa de mortalidade no período de 2013 a 2015 em clareiras no Município de Sumé-Semiárido da Paraíba, Brasil.

The floristic composition of the adult arboreal and shrub strata of the edges of the clearings comprised six species distributed in six genera and four families. The most wealthy family was Euphorbiaceae and Fabaceae, 
each with two species and two genera. The other families were composed only of one genus and one species. Habits were distributed homogeneously (Table 3).

Table 3. List of families and species recorded in the floristic survey of border vegetation in anthropic clearings in Caatinga area in the Paraíba Semi-arid, Brazil.

Tabela 3. Lista das famílias e espécies registradas no levantamento florístico da vegetação de borda em clareiras antrópicas em área de Caatinga no Semiárido da Paraíba, Brasil.

\begin{tabular}{lll}
\hline $\begin{array}{c}\text { Family } \\
\text { Species }\end{array}$ & Popular Name & Habit \\
\hline 1. Apocynaceae & Pereiro & Arboreal \\
$\begin{array}{l}\text { 1. Aspidosperma pyrifolium Mart. } \\
\text { 2. Combretaceae }\end{array}$ & Shrub \\
$\begin{array}{l}\text { 2. Combretum leprosum Mart. } \\
\text { 3. Euphorbiaceae }\end{array}$ & Marmeleiro & Shrub \\
$\begin{array}{l}\text { 3. Croton blanchetianus } \text { Baill. } \\
\text { 4. Jatropha mollissima } \text { (Pohl) Baill. }\end{array}$ & Shrub \\
$\begin{array}{l}\text { 4. Fabaceae } \\
\text { 4.1 Fabaceae subfam. Caesalpinioideae }\end{array}$ & Pinhão bravo & Arboreal \\
5. Poincianella pyramidalis (Tul.) L.P.Queiroz & & Catingueira \\
4.2 Fabaceae subfam. Mimosoideae & & Arboreal \\
6. Mimosa ophthalmocentra Mart. ex Benth. & Jurema de imbira \\
\hline
\end{tabular}

Considering the edge of the clearings, this was composed in 2013 by 595 individuals, already in the year 2015 this number decreased to 531 individuals due to mortality mainly of C. blanchetianus, which had $82.93 \%$ of its population reduced, followed by J. mollissima with $9.15 \%$. Despite the high mortality of C. blanchetianus in the year 2013, there were no newcomers of this species in 2015. In contrast J. molissima was the species with the highest number of individuals entering, with $94 \%$ (Figure 4).

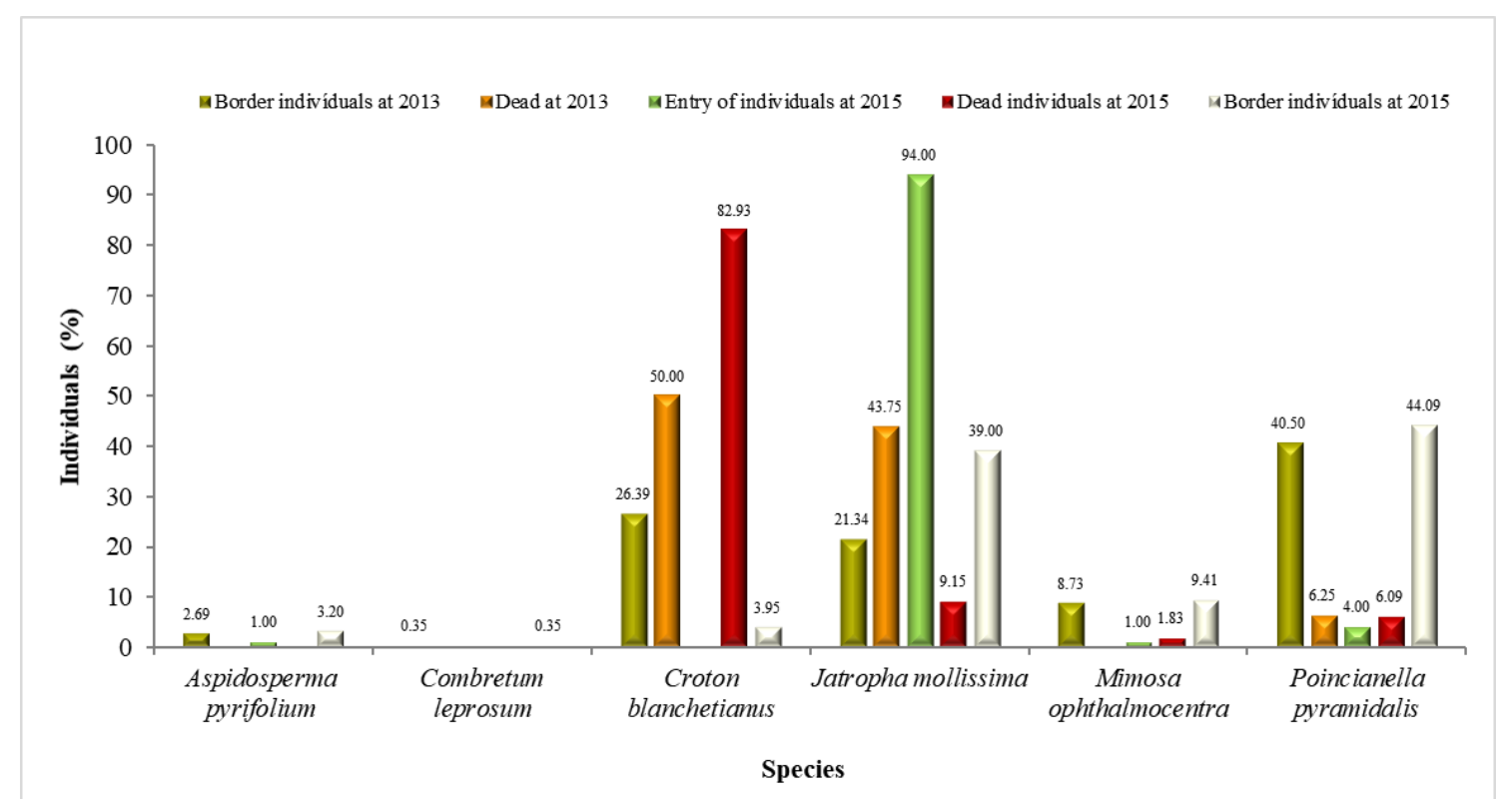

Figure 4. Dynamics of mortality and entry of individuals of arboreal and shrub species of clearings in the Caatinga area between 2013 and 2015 in the Paraíba Semi-arid, Brazil.

Figura 4. Dinâmica da mortalidade e ingresso de indivíduos de espécies arbóreas e arbustivas de clareiras em área de Caatinga entre o ano de 2013 e 2015 no Semiárido da Paraíba, Brasil

Climatic variations in the Brazilian Semi-arid region play important functions in the ecosystem dynamics. In extreme cases of water deficit, ecological processes do not stop, however, they adapt to each process. However,

FLORESTA, Curitiba, PR, v. 49, n. 3, p. 523 - 532, jul/set 2019.

Gomes, A. C. et.al.

ISSN eletrônico 1982-4688

DOI: $10.5380 /$ rf.v49 i 3.59715 
these adaptations tend to delay the successional evolution of the vegetation, since, instead of a greater species richness, there was a mean replacement of $90.05 \%$ C. blanchetianus by J. molissima, added to the addition of another $18.40 \%$ of the latter species, which was configured as more tolerant to the climatic conditions of the community studied.

The entry values of arboreal newcomers were very low. The highest percentage was $4 \%$ for $P$. pyramidalis followed by $M$. ophthalmocentra with $1.83 \%$ and A. pyrifolium with $1 \%$. There were no changes in the number of individuals of $C$. leprosum.

\section{DISCUSSION}

According Araujo et al. (2011) in Semi-arid conditions, with high temperatures and reduced plant cover, there is an intense carbonization of the organic matter in the soil that makes it difficult to decompose, resulting in the reduction of its contribution, thus being normal the low values of organic matter found in studied area. Oliveira et al. (2003), studying the chemical and physical attributes of soils, also found low levels of organic matter, which were attributed to the use of extensive livestock and subsistence crops without nutrient replacement to soil and semiarid conditions.

According to Lal (2004), soil organic matter is considered the main indicator of soil quality and its quantity depends on the input of organic material, its rate of mineralization, soil texture and climate. Due to its direct and indirect effects on soil properties, organic matter exerts a strong influence on the productive capacity of the soil.

The increase of soil density decreases the total porosity and macroporosity, resulting in decreased infiltration, oxygen availability and growth of the root system of the plants (KLEIN; LIBARDI, 2002). This fact has possibly contributed to the retardation of recolonization of clearings with higher soil densities, such as 3,4 , 10, 12 and 18, respectively, when compared to the other clearings.

Parente et al. (2010), when comparing the effect of trampling of goat with light and heavy loads and with a native Caatinga area without trampling, in two years, in São João do Cariri, obtained mean values of density of $1.45 ; 1.40$ and $1.45 \mathrm{~g} \mathrm{~cm}^{-3}$ for the respective treatments in 2007 and $1.53 ; 1.46$ and $1.49 \mathrm{~g} \mathrm{~cm}^{-3}$ in 2008 . These authors affirm that there was no significant difference in the loads of animals and area without trampling during the evaluated period, but higher loads over a long period can cause losses in the physical quality of the system and consequently in the biological quality.

In addition, to the species found at the edge of the clearings, Lacerda et al. (2018) recorded throughout the 96 plots that compose the studied area the presence of Schinopsis brasiliensis Eng., Varronia leucocephala (Moric.) JSMill., Morisonia flexuosa L., Pilosocereus gounellei (Weber) Byles and Rowlwy, Cereus jamacaru DC, Ditaxis sp., and Anadenanthera colubrina (Vell.) Brenan. In an area in initial state of ecological succession in the municipality of São João do Cariri, in Paraíba, Andrade et al. (2015) observed that after 30 years of regeneration, but still subject to goat herding, only five families and six species were recorded, Fabaceae and Euphorbiaceae being the richest. In general, these two families are the most important in most of the works related to the Caatinga (LACERDA et al., 2010).

Grau (2002) has shown that in spatially aggregated clearings, species richness values and the occurrence of groups of species intolerant to shade are correlated. In relation to the spatio-temporal pattern, the author suggests that the fact that more recent clearings occur closer to each other allows the seeds produced by species that have benefited from the presence of a clearing to have a greater chance of reaching new clearings that arise, because they are closer.

The climate is considered to be the outstanding characteristic of the Brazilian Semi-arid, and, therefore, has exerted important changes in the structure and functionality of the ecosystems. Despite having anthropic origin, all clearings have in their constitution small microenvironments with indicative of natural points, caused mainly by the mortality of individuals of the shrub component of the vegetation.

C. blanchetianus and J. molissima are classified as typically pioneer shrubs of Caatinga areas, whose function is to fill the areas with the highest luminosity rate within the forest. The high admission rate of $J$. molissima in the studied area may not only be a variable of the successional stage evolution, but an effect of the colonization of the clearings by species of greater tolerance to the drought, considering the low pluviometric indices recorded in the year 2015. Entering species $P$. pyramidalis, M. ophthalmocentra and A. pyrifolium are considered pioneers, according to Milk et al. (2015), revealing that the edge composition of the gaps is at an early stage of secondary succession.

The variability in pluviometric indexis causes strong changes in vegetation behavior and, consequently, in the entire ecosystem that tries to adapt to these variations that do not have a constant average over time. The changes in the climate, associated to the anthropic impacts, make the development of the biological chain too difficult. 
Silva et al. (2014), when studying 21 species of Caatinga, observed that J. molissima presented higher values of leaf thickness, leaf area, specific leaf area and dry leaf mass in relation to C. blanchetianus. According to Tribouillois et al. (2015), characteristics such as leaf dry mass, leaf area and leaf thickness are considered to be the main indicators of plant growth rate and the adjustments of these characteristics can be considered strategies developed to maximize the efficiency of the use of the different resources by plants. Thus, the relation of the physiological mechanisms of J. molissima and C. blanchetianus, associated with climatic factors and ecological function, justify the behavior of the dynamics of these species in the studied community.

According to Chazdon (2012), the vegetation dynamics processes associated with stages of secondary succession and time elapsed since the disturbance in tropical forests have great variations in the different regions of tropical forests and land uses. Phenomena that influence the replacement of a tree or shrub by others occur at small spatial scales and may form the basis of understanding the community organization that grows in a locality. Also attributed to these changes are the environmental heterogeneity created by the dynamics of clearings.

\section{CONCLUSIONS}

- The clearings of the studied area have anthropogenic origin, with low levels of organic matter, which are related to the clearings that had the highest soil density indexes, which may be influencing the composition and structure of the vegetation.

- The evolutionary edge dynamics in the studied period shows that the increase in the area of the clearings occurred due to the high mortality of $C$. blanchetianus, while the reduction occurred mainly due to the entry of J. molissima.

- The behavior of C. blanchetianus and J. molissima in the dynamics of the community is justified by the climatic factors of the region, associated with its physiological and ecological characteristics.

\section{ACKNOWLEDGMENTS}

To the $\mathrm{CNPq}$ for the granting of a master's degree in the Postgraduate Program in Agronomy (CCA/UFPB) offered to the first author and to the members of the Laboratory of Ecology and Botany LAEB/CDSA/UFCG and the Research Group on Ecosystem Conservation and Degraded Areas in the Semi-Arid - CERDES.

\section{REFERENCES}

AESA. Agência Executiva de Gestão das Águas do Estado da Paraíba. Tabelas de dados da estação de Sumé. Disponível em: http://pcd.aesa.pb.gov.br/?command=RTMCescreen=Tabela_Sume. Acesso em 01 de setembro de 2015.

ANDRADE, L. A.; PEREIRA, I. M.; LEITE, U. T.; BARBOSA, M. R. V. Analyses of the stract of two Caatinga physionomy in São João do Cariri, Paraiba State. Cerne, Lavras, v. 11, n. 3, p. 253-262, 2015.

ANSELMO, A. F.; KERPEL, S. M.; FERREIRA JUNIOR, A.; ZANELLA, F. C. V. Abundance, species richness and seasonality of butterflies (Lepidoptera: Hesperioidea and Papilionoidea) floral visitors in the Caatinga area and ciliary forest in the semi-arid Paraibano. Journal of Biology \& Pharmacy and Agricultural Management, Campina Grande, v. 10, n. 1, p. 97-110, 2014.

ARAUJO, K. D.; DANTAS, R. T.; ANDRADE, A. P.; PARENTE, H. N. Kinetics of carbon dioxide evolution in the caatinga area of São João do Cariri-PB. Revista Árvore, Viçosa, v. 35, n. 5, 2011.

BROKAW, N. V. L. Definition of tree fall gap and its effect on measures of forest dynamics. Biotropica, Washington, v.14, n.12, p. 158-60, 1982.

BROWN, N. The implications of climate and gap microclimate for seedling growth conditions in a Bornean lowland forest. Journal of Tropical Ecology, Winchelsea, v. 9, p. 153-168, 1993.

CHAZDON, R. L. Regeneration of tropical forests. Boletim do Museu Paraense Emílio Goeldi. Ciências Naturais, Belém, v. 7, n. 3, p. 195-218, 2012.

EMBRAPA. Sistema brasileiro de classificação de solos. Centro Nacional de Pesquisa de Solos: Rio de Janeiro: Embrapa, 2013. 353p.

FLORESTA, Curitiba, PR, v. 49, n. 3, p. 523 - 532, jul/set 2019.

Gomes, A. C. et.al.

ISSN eletrônico 1982-4688 
FERREIRA-KEPPLER, R. L.; RAFAEL, J. A.; GUERRERO, J. C. Seasonality and landscape use by tabanidae species (Diptera) in the Central Amazon, Brazil. Neotropical entomology, Santo Antônio de Goiás, v. 39, n. 4, p. 645-654, 2010.

FRAGOSO, M. G. L.; LACERDA, A. V.; LIMA, J. P. P.; Barbosa, F. M. Study of the Regressive ArborealArboreal and Mortality Strata in an Area of Initial Succession in Cariri Paraibano. In: SEABRA, Giovanni. (Org.) Terra - Saúde Ambiental e Soberania Alimentar. Ituiutaba Barlavento, 2015, v. III, p. 404p.

GRAU, H. R. Scale-dependent relationships between treefalls and species richness in a neotropical montane forest. Ecology, Washington, n.83, p. 2591-2601, 2002.

GUEDES, R. S.; ZANELlA, F. C. V.; COSTA JÚNIOR, J. E. V.; SANTANA, G. M.; SILVA, J. A. Floristicphytosociological characterization of the woody component of a caatinga stretch in the semi-arid region of Paraiba. Revista Caatinga, Mossoró, v. 25, n. 2, p. 99-108, 2012.

KLEIN, V. A.; LIBARDI, P. L. Hydraulic conductivity of a purple, unsaturated latosol, under different systems of use and management. Ciência Rural, Santa Maria, v.32, n. 6, p. 945-953, 2002.

LACERDA, A. V.; BARBOSA, F. M.; SOARES, J. J.; BARBOSA, M. R. V. Shrub-tree flora of three riparian areas in the semi-arid region of Paraíba, Brazil. Biota Neotropica, Campinas, v. 10, n. 4, p.275-284, 2010.

LACERDA, A. V.; LIMA, J. P. P.; NUNES, T. J. O.; GOMES, A. C.; DORNELAS, C. S. M.; ALCÂNTARA, H. M.; BARBOSA, F. M. Population Dynamics of Croton blanchetianus Baill. in a Caatinga Area in the Brazilian Semi-Arid. American Journal of Plant Sciences, Irvine, v. 9, n. 4, p. 920-932, 2018.

LAL, R. Soil Carbon Sequestration Impacts on Global. Science, Nova York, v.304, p.1623, 2004.

LEITE, J. A. N.; ARAUJO, L. V. C.; ARRIEL, E. F.; KEYS, L. F. C.; NOBREGA, A. M. F. Quantitative analysis of the Caatinga woody vegetation in Teixeira, PB. Pesquisa Florestal Brasileira, Colombo, v. 35, n. 82, p. 89$100,2015$.

MARTINS, S. V.; RIBEIRO, T. M.; GLERIANI, J. M.; AMARALI, C. H. D. Characterization of the natural regeneration canopy and stratum in the sub-forest and clearings of a Semideciduous Seasonal Forest in the Municipality of Viçosa, MG. Revista Árvore, Viçosa, v. 32, n. 4, p. 759-767, 2008.

OLIVEIRA, L. B.; RIBEIRO, M. R.; FERRAZ, F. B.; JACOMINE, P. K. T. Classification of planosolic soils of Sertão do Araripe. Revista Brasileira de Ciência do Solo, Viçosa, v. 27, p. 685-693, 2003.

PARENTE, H. N.; SILVA, D. S.; ANDRADE, A. P.; SOUZA, E. S.; ARAÚJO, K. D.; MAIA, M. O. Impact of goat trampling on soil attributes in caatinga area. Revista Brasileira de Saúde e Produção Animal, Salvador, v. 11, n. 2, 2010.

RIBEIRO, T. M.; MARTINS, S. V.; LANA, V. M.; SILVA, K. A. Survival and initial seedling growth of Euterpe edulis Mart. transplanted to clearings and understory in a semideciduous seasonal forest. Revista Árvore, Viçosa, v. 35, n. 6, p. 1219-1226, 2011.

SILVA, A. M. L.; LOPES, S. F.; VITORIO, L. A. P.; SANTIAGO, R. R.; MATTOS, E. A.; TROVÃO, D. M. B. M. Functional groups of plant species in semiarids ecosystems in Brazil: basic wood density and SLA as ecological indicator. Brazilian Journal of Botany, São Paulo, v.37, n.3, p.229-237, 2014.

SRINIVASAN, V. S.; SANTOS, C. A.; GALVÃO, G. C. O. Soil water wrosion in the Brazilian Semi-arid: The experiment in the experimental basin of Sumé. RBRH - Revista Brasileira de Recursos Hídricos, Porto Alegre, v. 8, n.2, p. 57-73, 2003.

TRIBOUILLOIS, H.; FORT, F.; CRUZ, P.; CHARLES, R.; FLORES, O.; GARNIER, E.; JUSTES, E. Functional characterization of a wide variety of hedge plant species: growth rates and nitrogen acquisition. PLoS ONE, San Francisco, v. 10, n. 3, p. 1-17, 2015. 